\title{
Efektivitas Pengelolaan Alokasi Dana Desa Pada Desa Silondou Kecamatan Basi Dondo Kabupaten Tolitoli
}

\section{The Effectiveness Of Managing The Allocation Of Village Funds In Silondou Village Basi Dondo District Tolitoli}

\author{
Hilmi $^{1}$, Ramlawati ${ }^{2}$ \\ Perencanaan Pembangunan, Stie Mujahidin Tolitoli \\ 1(hilmi@stiemujahidin.ac.id) \\ 2(ramlawati@stiemujahidin.ac.id )
}

\begin{abstract}
ABSTRAK
Penelitian ini bertujuan untuk mengetahui (1) tingkat efektivitas pengelolaan alokasi dana desa pada Desa Silondou tahun 2014-2019, (2) hambatan yang dihadapi dalam merealisasi alokasi dana desa pada Desa Silondou, (3) cara menanggulangi hambatan dalam merealisasi alokasi dana desa pada Desa Silondou. Jenis penelitian ini adalah deskriptif. Data dikumpulkan dengan metode dokumentasi dan wawancara. Analisis data menggunakan teknik efektivitas dan rasio kreteria efektivitas. Hasil penelitian menunjukkan (1) Efektivitas pengelolaan alokasi dana desa dari tahun 2014-2019 sudah berada dalam kategori efektif. Tingkat efektivitas pengelolaan alokasi dana desa pada Desa Silondou yaitu tahun 2014 (98,98\%), 2015 (100\%), 2016 (100\%), 2017 (98,24\%), 2018 (100\%), dan 2019 (99,57\%). (2) Hambatan yang dialami dalam merealisasi alokasi dana desa pada Desa Silondou adalah pemahaman masyarakat terhadap ADD, miss komunikasi , dan pencairan alokasi dana desa yang terlambat. (3) menanggulangi hambatan dalam merealisasi alokasi dana desa dapat dilakukan dengan pelatihan, meningkatkan koordinasi unit kerja, dan anggaran dana cadangan.
\end{abstract}

.Kata Kunci : Efektivitas, pengelolaan, alokasi dana desa

\section{ABSTRACT}

This research is a purpose to understand (1) the effectiveness of management of village funds allocation in Silondou village in years 2014-2019, (2) obstacles that faced in realization village funds allocation in Silondou village, (3) cope with the obstacles in realization village funds allocation in Silondou village. The design is descriptive research. Data were collected with the documentation and interview. The result showed (1) management effectiveness village funds allocation from years 2009-2014 referring to be in category effective. The effectiveness management village funds allocation in Silondou villages year 2014 (98,98\%), 2015 (100\%), 2016 (100\%), 2017 (98,24\%), 2018 (100\%), and 2019 (99,57\%). (2) obstacles experienced in realization Silondou village funds allocation is the comprehension of human resources remain low, miss-communication, and liquefaction the village funds allocation late. (3) cope with the obstacles of realization village funds allocation can do with coaching, increase coordination, and make fund reserve.

KeyWords : Effectiveness, allocation, of village fund management

\section{PENDAHULUAN}

Kegagalan berbagai program pembangunan pedesaan di masa lalu disebabkan antara lain karena penyusunan, pelaksanaan dan evaluasi program-program pembangunan pedesaan tidak melibatkan masyarakat. Pembangunan dilakukan dengan tidak aspiratif dan parsitipatif. Proses kebijakan pembangunan lebih mengedepankan paradigma politik sentralistis dan dominannya peranan negara pada arus utama kehidupan bermasyarakat. 
Akibat dari mekanisme perencanaan pembangunan yang tidak aspiratif dan kurang partisipatif tersebut, membuat hasil perencanaan dan proses pembangunan, terutama di tingkat Desa sering menjadi tidak berkelanjutan. Undang-Undang Nomor 32 Tahun 2004 Tentang Desa memberikan kesempatan kepada masyarakat desa untuk mengatur dan mengurus rumah tangganya sendiri, dengan persyaratan yang diamanatkan dalam undang-undang tersebut, yakni diselenggarakan dengan memperhatikan prinsip-prinsip demokrasi, peran serta masyarakat, pemerataan, keadilan, serta memperhatikan potensi dan keaneka-ragaman daerah.

Pada tahun 2005 pemerintah mengeluarkan kebijakan Alokasi Dana Desa (ADD), yang ditandai dengan terbitnya Peraturan Pemerintah Nomor 72 Tahun 2005, yang menyebutkan bahwa desa adalah kesatuan masyarakat hukum yang memiliki batas-batas wilayah yang berwenang untuk mengatur kepentingan masyarakat setempat, berdasarkan asal-usul dan adat istiadat setempat yang diakui dan dihormati dalam sistem Pemerintahan Negara Kesatuan Republik Indonesia. Dan pemerintahan desa berdasarkan PP No. 72 Tahun 2005 adalah penyelenggaraan urusan pemerintahan oleh Pemerintahan Desa dan Badan Permusyawaratan Desa dalam mengatur dan mengurus kepentingan masyarakat setempat berdasarkan asal-usul dan adatistiadat setempat yang diakui dan dihormati dalam sistem Pemerintahan Negara Kesatuan Republik Indonesia.

Pelaksanaan ADD diatur oleh pemerintah dalam Peraturan Pemerintah Nomor 72 Tahun 2005 tentang Desa. Peraturan mengenai alokasi dana desa (ADD) ditindak lanjuti melalui Surat Edaran Menteri Dalam Negeri Nomor 140/640/SJ Tahun 2005 tentang Pedoman Alokasi Dana Desa (ADD) dari pemerintah Kabupaten/Kota kepada pemerintah Desa yang intinya berisi mengenai prosedur pelaksanaan alokasi dana desa. Untuk menindaklanjuti PP Nomor 72 Tahun 2005 tentang Desa serta Surat Edaran Mendagri Nomor 140/640/SJ tentang Pedoman Alokasi Dana Desa salah satunya mengatur tentang Penggunaan Alokasi Dana Desa (ADD) yakni alokasi dana desa yang diterima Pemerintah Desa sejumlah $30 \%$ dipergunakan untuk biaya operasional penyelenggaraan pemerintahan Desa. Kemudian alokasi dana desa yang diterima pemerintah Desa sejumlah $70 \%$ dipergunakan untuk pembangunan fisik dan pemberdayaan masyarakat Desa. Pembangunan di desa merupakan model pembangunan partisipatif yaitu suatu sistem pengelolaan pembangunan bersama-sama, yang direncanakan, dilaksanakan dan dievaluasi secara musyawarah, mufakat, dan gotong royong, yang merupakan cara hidup masyarakat yang telah lama berakar budaya wilayah Indonesia. Sebagaimana disebutkan dalam pasal 5 Permendagri No 66 tahun 2007, karakteristik pembangunan partisipatif diantaranya direncanakan dengan pemberdayaan dan partisipatif. Pemberdayaan, yaitu upaya untuk mewujudkan kemampuan dan kemandirian masyarakat dalam kehidupan bermasyarakat, berbangsa dan bernegara sedangkan partisipatif, yaitu keikutsertaan dan keterlibatan masyarakat secara aktif dalam proses pembangunan. Pembangunan di desa menjadi tanggungjawab kepala desa. Kepala desa mempunyai tugas menyelenggarakan urusan pemerintahan, pembangunan, dan kemasyarakatan. Dalam pelaksanaan pembangunan, Kepala Desa dibantu oleh perangkat Desa dan dapat dibantu oleh lembaga kemasyarakatan di Desa. Desa Silondou merupakan salah satu desa yang terletak di Kecamatan Basi Dondo, Kabupaten Tolitoli.

Berkaitan dengan bantuan alokasi dana desa, Desa Silondou mendapatkan dana bantuan tersebut dari tahun 2014 meskipun aturan tentang alokasi dana desa sudah ada sejak 
2005. Jumlah rupiah alokasi dana desa ditargetkan dan terealisasi pada Desa Silondou pada tahun yaitu (1) 2014 target sebesar Rp.85.371.000, terealisasi sebesar Rp.84.500.000, (2) 2015 target sebesar Rp.76.856.200, terealisasi sebesar Rp.76.856.200, (3) 2016 target sebesar Rp.211.254.000,terealisasi sebesar Rp.211.254.000, (4) 2017 target sebesar Rp.205.405.000, terealisasi sebesar Rp.201.783.500, (5) 2018 target sebesar Rp.205.405.000, terealiasi Rp.205.405.000, (6) 2019 target sebesar 568.064.000, terealisasi sebesar 565.572.000.

Dari penjelasan diatas ditemukan permasalahan yang muncul bahwa kesamaan antara target dengan realisasi program alokasi dana desa tiap tahunnya cenderung fluktuasi, hal ini cukup menandakan bahwa kemampuan masyarakat baik sebagai subyek dan obyek program alokasi dana desa masih kurang matang. Terlepas dari masyarakat desa, hambatan dalam merealisasi alokasi dana desa bisa saja datang dari pihak luar atau bahkan keadaan alam dan sosial Desa Silondou. Hambatan-hambatan ini seharusnya dapat dketahui dan dicarikan solusi yang tepat, agar dapat ditindaklanjuti untuk meningkatkan pengelolaan alokasi dana desa secara lebih maksimal. Alasan peneliti memilih alokasi dana desa sebagai bahan penelitian dikarenakan alokasi dana desa mempunyai pengaruh yang besar dalam pembangunan di Desa, dibandingkan dengan sumber-sumber dana pendapatan Desa yang lain. Apabila alokasi dana desa benar-benar dikelola dengan baik dan jujur maka bukan tidak mungkin program ini akan meningkatkan pelayanan publik di pedesaan, partisipasi masyarakat dalam pembangunan akan meningkat, dan tentu saja akan bermuara pada kesejahteraan masyarakat desa. Oleh karena itu, peneliti melaksanakan penelitian dengan judul " Efektivitas Pengelolaan Alokasi Dana Desa (ADD) Pada

\section{Desa Silondou Kecamatan Basi Dondo, Kabupaten Tolitoli Tahun 2014-2019.}

\section{METODE}

Jenis penelitian ini adalah penelitian deskriptif. Penelitian ini dilakukan di Desa Silondou. Fokus pengamatan dalam penelitian ini adalah tentang efektivitas pengelolaan alokasi dana desa pada Desa Silondou tahun 2014-2019. Dalam penelitian ini, peneliti melakukan observasi secara mendalam dengan pihak pemangku kepentingan (stakeholders) pemerintah desa untuk mendapatkan informasi dan dokumen-dokumen yang berkaitan dengan penelitian yang dilakukan oleh peneliti. Penelitaian ini bermaksud untuk memberikan informasi tentang efektivitas pengelolaan alokasi dana desa pada Desa Silondou dari tahun 2014-2019, beserta hambatan dalam merealisasi dan cara untuk menanggulanginya. Sehingga diharapkan penelitian ini dapat memberikan dampak positif dalam perbaikan pengelolaan alokasi dana desa.

Berdasarkan jenis data, Penelitian ini menggunakan data kualitatif dan kuantitatif. Data kualitatif adalah data yang tidak dapat diukur dan dihitung tetapi dapat memberikan informasi tambahan bagi peneliti. Dalam hal ini data seperti informasi tentang program pemerintah yang berkaitan dengan pembangunan fisik dan pemberdayaan masyarakat desa, serta laporan pertanggung jawaban yang dibuat oleh pemerintah desa. Data kuantitaif adalah data berupa angka yang dapat dihitung secara nyata. Dalam hal ini data kuatitatif seperti jumlah alokasi dana desa yang diterima, alokasi dana desa yang dianggarkan untuk program pemerintahan dan seberapa besar alokasi dana desa yang telah terrealisasi. Dalam melaksanakan penelitian ini, peneliti menggunakan teknik pengumpulan data dengan menggunakan metode dokumentasi dan wawancara. Metode dokumentasi adalah metode pengumpulan data yang dilakukan dengan mengambil data dari berbagai sumber 
dokumentasi atau publikasi dari berbagai pihak yang berwenang, instansi terkait seperti pemerintah desa Silondou. Dokumen yang dimaksud meliputi data laporan keuangan beserta laporan target dan realisasi dari pengelolaan alokasi dana desa, peraturan tentang alokasi dana desa, dan data yang berkaitan dengan penelitian yang dilakukan. Wawancara digunakan untuk memperoleh data berupa penjelasan dari Kepala Desa Silondou mengenai hambatan yang dialami oleh pihak pemerintah desa dalam merealisasi alokasi dana desa, serta usaha apa yang telah dilakukan untuk menanggulangi hambatan yang ada. Wawancara yang digunakan berupa wawancara tidak terstruktur. Pengujian instrumen dilakukan dengan cara sebagai berikut.

\section{ANALISIS EFEKTIVITAS}

Efektivitas menggambarkan kemampuan pemerintah desa dalam merealisasi keuangan alokasi dana desa untuk melaksanakan program yang direncanakan dibandingakan dengan target yang telah detetapkan berdasarkan potensi nilai rill Abdul Halim (2002:136). Analisis yang digunakan untuk menghitung tingkat efektivitas alokasi dana desa pada Desa Silondou dari tahun 20142019 menggunakan rumus sebagai berikut : (LPJ Keuangan Desa Silondou Depdagri, Kemendagri no 690.900.327).

Efektivitas $=\frac{\text { Realisasi ADD }}{\text { Target ADD }} \times 100 \%$

Efektivitas suatu organisasi dikatakan baik apabila rasio yang dicapai minimal $90 \%$ sampai dengan $100 \%$, tetapi alangkah lebih baik lagi jika organisasi tersebut mampu memperoleh lebih besar dari itu, adapun kriteria rasio efektivitas yang akan digunakan dalam penelitian ini adalah sebagai berikut :

\section{KRITERIA RASIO EFEKTIVITAS}

Rasio efektivitas digunakan untuk memudahkan dalam memberikan kesimpulan dari perhitungan yang telah dilakukan melalui analisis efektivitas. Adapun rasio efektivitas yang digunakan Depdagri, Kemendagri no 690.900.327, yaitu :

1) Hasil perbandingan antara realisasi dengan target alokasi dana desa jika pencapaiannya diatas $100 \%$ dapat dikatakan sangat efektif,

2) Hasil perbandingan antara realisasi dengan target alokasi dana desa jika tingkat pencapaiannya 90-100\% dapat dikatakan efektif,

3) Hasil perbandingan antara realisasi dengan target alokasi dana desa jika tingkat pencapaiannya 80-89 \% dapat dikatakan cukup efektif,

4) Hasil perbandingan antara realisasi dengan target alokasi dana desa jika tingkat pencapaiannya 60-79 \% dapat dikatakan kurang efektif,

5) Hasil perbandingan antara realisasi dengan target alokasi dana desa jika tingkat pencapaiannya $<60 \%$ dapat dikatakan tidak efektif.

\section{HASIL DAN PEMBAHASAN}

Berdasarkan perhitungan yang dilakukan melalui analisis efektivitas, dapat dipaparkan efektivitas pengelolan alokasi dana desa pada Desa Silondou tahun 2014-2019 sebagai berikut:

$$
\text { Tahun } \begin{aligned}
2014 & =\frac{\text { Rp.84.500.000 }}{\text { Rp.85.371.000 }} \times 100 \% \\
& =98,98 \%
\end{aligned}
$$

Tahun $2015=\frac{\text { Rp.76.856.200 }}{\text { Rp.76.856.200 }} \times 100 \%$

$$
=100 \%
$$

Tahun $2016=\frac{\text { Rp.211.254.000 }}{\text { Rp.211.254.000 }} \times 100 \%$ 


$$
=100 \%
$$

Tahun $2017=\frac{\text { Rp.201.783.500 }}{\text { Rp.205.405.000 }} \times 100 \%$

$$
=98,24 \%
$$

Tahun $2018=\frac{\text { Rp.205.405.000 }}{\text { Rp.205.405.000 }} \times 100 \%$

$$
=100 \%
$$

Tahun $2019=\frac{\text { Rp.565.572.000 }}{\text { Rp. } 568.064 .000} \times 100 \%$

$$
=99,57 \%
$$

Berdasarkan kreteria rasio efektivitas, pengelolaan alokasi dana desa pada desa Silondou dari tahun 2014-2019 berada pada kategori efektif, karena tingkat efektivitasnya berada pada angka 90-100\%. Hal ini sesuai dengan kriteia rasio efektivitas.

\section{Hambatan Dalam Merealisasikan Alokasi Dana Desa di Desa Silondou}

Berdasarkan penelitian yang telah dilakukan, peneliti menemukan beberapa hal yang dapat menghambat terealisasinya alokasi dana desa sesuai dengan target yang telah ditentukan sebelumnya. Adapun penghambat yang dimaksud adalah sebagai berikut :

Pertama, pemahaman masyarakat terhadap ADD. Pemahaman masyarakat terhadap alokasi dana desa. Dari hasil wawancara yang telah dilakukan, permasalahan yang ditemukan oleh pemerintah desa dalam merealisasi alokasi dana desa sesuai dengan target adalah menumbuhkan kesadaran bagi masyarakat desa bahwa mereka adalah pihak yang berkepentingan (stakeholder) dalam pengelolaan alokasi dana desa.

Pemahaman tentang peran masyarakat desa sebagai perencana, pelaksana dan pengevaluasi program yang masih kurang menyebabkan ada kecendrungan masyarakat kurang berpartisipasi dalam program alokasi dana desa, meskipun sudah ada masyarakat yang ikut berperan aktif dalam pengelolaan alokasi dana desa namun hasilnya tidaklah signifikan, karena jumlah masyarakat yang sudah berpartisipasi jauh lebih sedikit dibandingkan masyarakat yang belum berpartisipasi. Kurangnya partisipasi masyarakat desa dalam program alokasi dana desa seringkali menyebabkan pemborosan biaya.

Tenaga masyarakat dalam pembangunan desa, khususnya pada pembangunan fisik/infrsatruktur sangat diperlukan oleh pemerintah desa untuk menekan biaya yang akan dikeluarkan khususnya biaya tenaga kerja.

Pemborosan biaya berdampak pada terganggunya program yang lain, karena dana yang akan dipakai untuk membiayai program yang lain tersebut dipakai untuk menutupi biaya upah tenaga kerja, sehingga pemerintah desa harus menunda program yang telah direncanakan sebelumnya sampai ada dana yang mencukupi. Pemerintah desa sebenarnya sangat mengharapkan kesadaran dari semua masyarakat desa untuk membantu mengelola alokasi dana desa agar berjalan efektif dengan maksimal, namun karena mayoritas masyarakat desa adalah lulusan SD bahkan ada yang sama sekali tidak sekolah mengakibatkan adanya kecenderungan pemahaman tentang alokasi dana desa yang sulit untuk ditumbuhkan dalam pemikiran masyarakat sehingga masyarakat juga kurang memahami tujuan dari alokasi dana desa dan kewajiban mereka sebagai pengelola langsung dari alokasi dana desa tersebut.

Kedua, terjadinya miss komunikasi antar unit kerja. Berdasarkan hasil wawancara kepada pihak pemerintah desa Silondou disebutkan bahwa dalam melaksanakan program alokasi dana desa sering terjadi miss komunikasi yang disebabkan oleh kurangnya koordinasi antar unit kerja. Miss komunikasi antar unit kerja sering memicu terjadinya kesalahan dalam pelaksanaan program alokasi dana desa. Kepala Desa Silondou menjelaskan bahwa, meskipun telah direncanakan

Ecanamy Depasit Jaurnal Volume 2 No 2, Desember 2020 
sebelumnya namun program pemerintah khususnya alokasi dana desa tidaklah akan selalu konsisten dalam perjalanannya, karena program yang telah ditentukan bisa saja berubah sewaktu-waktu tanpa direncanakan. Karena adanya perubahan program ini sering terjadi miis komunikasi baik dari pihak internal pemerintah, pihak pemerintah dengan masyarakat, serta pihak pemerintah dengan stakeholder. Akibatnya pelaksanaan program alokasi dana desa tidak tercapai sesuai dengan rencana, bahkan menyebabkan adanya kecenderungan pemborosan biaya.

Ketiga, pencairan alokasi dana desa yang terlambat. Berdasarkan informasi yang didapatkan peneliti dari Kepala Desa Silondou tidak tepatnya waktu pencairan alokasi disebabkan oleh proses yang cukup panjang yaitu mekanisme pengajuan, penyimpanan nomor rekening, transfer, surat permintaan pembayaran, dan lain sebagainya.

Alokasi dana desa tidak bisa dicairkan satu kali, melainkan harus dicairkan pada saat program-program yang akan dibiayai oleh alokasi dana desa sudah akan dilaksanakan, hal ini juga telah disebutkan dalam laporan pertanggungjawaban (LPJ) yang dibuat oleh pemerintah desa Silondou. Berkaitan dengan pelaksanaan program, pemerintah desa Silondou mengambil kebijakan untuk menggunkan stakeholder eksternal dengan sistem borongan, terutama dalam program pembangunan fisik. Langkah ini diambil karena adanya pandangan bahwa sistem borongan tersebut dapat meminimalkan biaya pembangunan, dari pada menggunakan buruh dengan sistem upah harian. Namun seiring dengan berjalannya program, pemborong proyek sering berhenti di tengah jalan. Hal ini cenderung disebabkan karena dana yang dibutuhkan untuk melanjutkan proyek tersendat atau belum dicairkan, sehingga proyek pembangunan tertunda hingga kurun waktu yang tidak dapat ditentukan karena menunggu dana untuk membiayai proyek tersebut.
Pencairan dana yang tidak tepat selain karena mekanisme yang cukup lama juga disebabkan oleh tidak tepatnya perhitungan awal yang dilakukan oleh pemerintah desa dengan pihak stakeholder. Kesalahan perhitungan ini sering membuat pihak pemborong proyek meminta dana tambahan secara mendadak karena dana untuk proyek habis dengan waktu yang tidak tentu.

Mengingat pencairan alokasi dana desa yang harus melewati mekanisme yang cukup panjang menyebabkan pemerintah desa tidak dapat menyiapkan dana sesuai kebutuhan dari pihak stakeholder, sehingga membuat proyek terhenti di tengah jalan. Proyek yang terhenti tentunya akan menghambat realisasi program yang sudah ditargetkan, karena program pemerintahan juga menuntut ketepatan waktu.

\section{Cara Menanggulangi Hambatan dalam Merealisasi Alokasi Dana Desa di Desa Silondou}

Meskipun dalam merealisasi alokasi dana desa menemui hambatan, bukan berarti hambatan tersebut tidak dapat ditanggulangi. Berdasarkan hasil wawancara peneliti dengan pihak pemerintah desa hambatan yang dialami dalam merealisasi alokasi dana desa dapat minimalisasi dengan cara sebagai berikut :

Pertama, mengadakan pelatihan untuk program alokasi dana desa. Kurangnya pemahaman sumber daya manusia dalam mengelola alokasi dana desa, dapat ditanggulangi melaui pelatihan. Pelatihan akan berperan dalam memberikan wawasan dan keterampilan kepada sumber daya manusia yang dalam hal ini adalah aparatur pemerintah Desa Silondou pada khususnya dan masyarakat desa pada umumnya. Dengan adanya wawasan yang dimiliki oleh aparatur pemeritah desa dan masyarakat maka akan memberikan kemampuan untuk merencanakan dan menyusun program-program dalam alokasi dana desa secara lebih matang. Keterampilan yang didapat dari pelatihan akan membantu 
aparatur pemerintah desa Silondou dalam melaksanakan dan mengevaluasi programprogram yang dibuat melalui alokasi dana desa. Pelatihan ini diadakan bukan atas dasar kepentingan pemerintah desa saja, namun pelatihan ini diharapkan dapat menyentuh kepada masyarakat. Pelatihan diadakan bertujuan untuk membantu masyarakat dalam menumbuhkan pemahaman bahwa mereka adalah pihak berkepentingan yang seharusnya berperan aktif dalam mengelola alokasi dana desa. Wawasan dan keterampilan yang didapat masyarakat melalui pelatihan akan membuat mereka memiliki kemampuan untuk aktif dan berpartisipasi dalam mengelola alokasi dana desa, sehingga pengelolaan alokasi dana desa akan menjadi lebih efektif, efisien, dan ekonomis.

Kedua, meningkatkan koordinasi antar unit kerja. Berdasarkan wawancara yang telah dilakukan peneliti dengan pihak pemerintah desa, dapat dijelaskan bahwa miss komunikasi yang sering terjadi dalam pengelolaan alokasi dana desa dapat ditanggulangi dengan meningkatkan koordinasi antar unit kerja. Koordinasi yang baik sangat diperlukan dalam pencapain program pemerintah desa, terlebih lagi program yang bisa berubah tanpa direncanakan. Koordinasi yang efektif dapat membantu pemerintah desa dalam melaksanakan tugas-tugasnya agar dapat berjalan dengan lancar sehingga tidak merugikan pemerintah desa dan masyarakat desa. Koordinasi yang efektif maksudnya adalah koordinasi yang terpusat sehingga ada unsur pengendalian guna menghindari tiap bagian bergerak sendiri-sendiri. Setiap bagian unit kerja organisasi pemerintah desa harus berkesinambungan,yaitu rangkaian kegiatannya harus saling menyambung guna menegaskan bahwa adanya keterkaitan antar unit organisasi dalam pencapaian program alokasi dana desa sehingga setiap unit akan memberikan informasi yang relevan untuk menghindarkan tumpang tindih tugas yang satu dengan tugas yang lainnya.

Ketiga, pengalokasian dana cadangan. Berdasarkan penelitian yang telah dilakukan peneliti melalui wawancara dapat dijelaskan bahwa program pemerintahan yang sering terhenti disebabkan karena ketidaktepatan pencairan dana desa. Pencairan dana desa tidaklah cepat karena harus melalui mekanisme pencairan yang cukup panjang. Oleh karena itu disaat stakeholder memerlukan dana tambahan secara dadakan pemerintah desa tidak dapat secara langsung menyediakan dana tersebut, karena masih menunggu pencairan dana desa. Melihat adanya hambatan tersebut, pemerintah desa melakukan suatu strategi dengan cara membuat anggaran dana cadangan yang dikhususkan untuk mengantisipasi jika diperlukan dana yang mendesak untuk membiayai program pemerintahan, sehingga tidak menghentikan program dengan waktu yang tidak bisa ditentukan. Dana cadangan ini disimpan pada Lembaga Perkreditan Desa (LPD) Silondou, karena pemerintah desa tidak memungkinkan menyimpan dana yang relatif besar dikantor desa. Selain itu, melalui simpanan tersebut secara tidak langsung pemerintah desa dapat membantu LPD dalam melancarkan peredaran uang di Desa, khusunya dalam hal pinjaman disamping bunga yang diharapkan pemerintah desa dari simpanan dana cadangan terebut. Pencairan dana di LPD Silondou juga tidak terlalu rumit, sehingga ketika adanya permintaan dana yang mendesak dapat disediakan dalam waktu yang cukup cepat.

\section{PEMBAHASAN}

Dari penelitian yang telah dilakukan peneliti melalui metode dokumentasi, dapat dijelaskan bahwa alokasi dana desa yang diterima oleh pemerintah Desa Silondou dari tahun 2014 sampai dengan 2019 mengalami fluktuasi, dimana jumlah rupiah yang diterima cenderung mengalami perubahan. Efektivitas pengelolaan 
alokasi dana desa dari tahun 2014 sampai dengan 2019 pada Desa Silondou, Kecamatan Basi Dondo, Kabupateen Tolitoli. sudah berada dalam kategori efektif. Namun tidak semua tingkat efektivitas berada dalam angka 100\%, ini disebabkan karena ada target yang tidak dapat terealisasi dengan maksimal. Hal ini sudah sesuai dengan teori dari Depdagri, Kemendagri no. 690.900.327 yang menyatakan bahwa, jika tingakt efektivitas atau hasil perbandingan antara realisasi dengan target alokasi dana desa (ADD) jika tingkat pencapaiannya pada angka 90-100\%, maka dapat dikatakan dalam kategori efektif. Adapun tingkat efektivitas pengelolaan alokasi dana desa pada Desa Silondou tahun 2014 (98,98\%), tahun 2015 (100\%), tahun 2016 (100\%), tahun 2017 (98,24\%), tahun 2018 (100\%), dan tahun 2019 (99,57\%). Dalam merealisasi dana desa yang jumlahnya tidak sedikit memang bukan pekerjaan yang mudah karena memerluka strategi yang tepat, mulai dari perencanaan, pelaksanaan, hingga evaluasinya. Terlebih lagi dana desa merupakan dana yang ditujukan untuk membangun daerah pedesaan agar lebih mandiri dan sejahtera, sehingga pengelolaannya harus tepat sasaran sesuai dengan maksud dan tujuan alokasi dana desa tersebut.

Berdasarkan penelitian yang dialakukan peneliti melalui metode wawancara, ditemukan bahwa hambatan yang dialami pemerintah desa dalam merealisasi alokasi dana desa secara umum adalah sebagai berikut :

1) Kurangnya pemahaman masyarakat terhadap alokasi dana desa, hal ini berdampak terhadap kurannya partisipasi oleh masyarakat dalam perencanaan, pelaksanaan, dan evaluasi program. Kurangnya partisipasi masyarakat dalam pengelolaan program ADD akan berdampak pada realisasi yang tidak maksimal.

2) Terjadinya miss komunikasi antar unit kerja, hal ini disebabkan oleh kurangnya koordinasi yang terjadi pada internal pemerintah desa, pemeritah desa dengan masyarakat dan pemerintah desa dengan stakeholders eksternal. Hal ini menyebabkan kecenderungan realisasi alokasi dana desa tidak sesuai target yang ditetapkan, dan

3) Pencairan dana desa yang terlambat. Terlambatnya pencairan alokasi dana desa disebabkan oleh mekanisme yang cukup panjang, sehingga ketika ada keperluan dana yang mendesak untuk membiayai program tidak dapat dipenuhi dengan cepat. Akibatnya program yang telah dijalankan harus tertunda dalam waktu yang tidak bisa ditentukan, sehingga realisasi program menjadi terhambat karena harus menunggu tersedianya dana.

Hambatan yang muncul dalam merealisasikan alokasi dana desa pada desa Silondou dapat ditanggulangi dengan cara.

1) Mengadakan pelatihan untuk program alokasi dana desa yang bertujuan untuk menambah wawasan dan keterampilan sumber daya manusia pemerintah desa dan masyarakat sehingga dapat merencanakan, melaksanakan, dan mengevaluasi program yang dibiayai melalui alokasi dana desa dengan tepat. Hal ini telah diatur dalam peraturan pemerintah Republik Indonesia Nomor 43 Tahun 2014 tentang Peraturan Pelaksanaan Undang-undang Nomor 6 tahun 2014 tentang Desa pasal 128 yang menyebutkan bahwa " pemerintah dan pemerintah daerah menyelenggarakan pemberdayaan masyarakat desa dengan pendampingan secara berjenjang sesuai dengan kebutuhan, pendampingan masyarakat secara teknis dilaksanakan oleh satuan kerja perangkat daerah kabupaten/ kota dan dapat dibantu oleh tenaga pendamping profesional, kader pemberdayaan masyarakat, dan/atau pihak ketiga serta camat atau sebutan lain 
melakukan koordinasi pendampingan masyarakat desa di wilayahnya ".

2) Meningkatkan koordinasi antar unit kerja. Meningkatkan koordinasi merupakan cara yang tepat untuk menanggulangi miss komunikasi yang sering terjadi pada unit kerja organisasi pemerintah desa, karena dengan meningkatkan koordinasi setiap unit kerja akan selalu berinteraksi sehingga tidak terjadi tumpang tidih pekerjaan satu dengan yang lainnya. Mardiasmo (2002:65) disebutkan bahwa " koordinasi anggaran yang baik akan mampu mendeteksi terjadinya inkonsistensi suatu unit kerja dalam mencapai tujuan organisasi.

3) Pengalokasian dana cadangan. Menanggulangi program yang terdunda pelaksanaannya akibat terlambatnya pencairan dana dapat dilakukan dengan membuat anggaran berbeda yang disebut dengan dana cadangan. Dana cadangan ini berfungsi untuk mengantisipasi jika diperlukan dana yang mendesak untuk membiayai program, sehingga tidak membuat program yang seharusnya dapat terlaksaana menjadi tertunda. Mardiasmo (2002: 152) disebutkan bahwa masalah utama organisasi sektor publik adalaah alokasi dana dan pencairan dana. Tiap dana harus dipisahkan dalam laci terpisah sehingga dapat dikeluarkan apabila ada otoritas dari pihak perencana dan pelaksana karena adanya tuntutan.

\section{KESIMPULAN DAN SARAN}

Berdasarkan analisis data yang telah dilakukan maka dapat dibuat simpulan halhal sebagai berikut :

1) Efektivitas pengelolaan alokasi dana desa pada Desa Silondou, Kecamatan Basi Dondo,

Kabupaten Tolitoli tahun 2014 sampai dengan 2019 berada pada kategori efektif, karena tingkat efektivitas tiap tahun berada pada angka 90\%-100\% (efektif). Tingkat efektivitas masing-masing tahun yaitu 2014 (98,89\%), 2015 (100\%), tahun 2016 (100\%), tahun $2017(89,24 \%)$, tahun 2018 (100\%), dan tahun $2019(99,57 \%)$.

2) Adapun hambatan yang dialami oleh pemerintah desa dalam merealisasi alokasi dana desa pada Desa Silondou, Kecamatan Basi Dondo, Kabupaten Tolitoli yaitu Pemahaman masyaraakat terhadap ADD, terjdinya miss komunikasi antar unit kerja baik dalam internal pemerintah desa, pemerintah dengan maasyarakat, dan pemerintah dengan stakeholders, dan pencairan alokasi dana desa yang tidak tepat.

3) Untuk menanggulangi hambatan dalam merealisasi alokasi dana desa dapat dilakukan dengan beberapa cara yaitu : Mengadakan pelatihan tentang alokasi dana desa untuk masayarakat dan aparatur pemerintah desa, meningkatkan koordinasi antar unit kerja, membuat anggaran untuk dana cadangan program.

Berdasarkan hasil penelitian yang telah disimpilkan diatas, peneliti dapat memberikan saran sebagai berikut :

1) Untuk menanggulangi pemahaman masyarakat yang masih kurang terhadap ADD selain mengadakan pelatihan pemerintah desa juga harus mampu memberikan sosialisasi yang tepat kepada masyarakaat tentang peran mereka dalam mengelola ADD, sehingga berpotensi membuat pemahaman masyarakat akan terus meingkat.

2) Untuk menanggulangi miss komunikasi antar unit kerja selain meningatkan koordinasi, pemerintah harus mampu menjaga harmonisasi antar unit kerja, sehingga ketika terjadinya miss komunikasi tidak terjadi konflik yang 
dapat merugikan pemerintah desa pada khususnya dan masyarakat desa pada umumnya.

3) Untuk menanggulangi keterlambatan pencairan dana selain dengan dengan membuat anggaran terpisah untuk dana cadangan, pemerintah dengan pihak stakeholders hendaknya membuat perjanjian bahwa ketika membutuhkan dana tidak boleh dinformasikan dan diminta dengan kurun waktu yang pendek. Penyampaina informasi dapat dilakukan kurang lebih 1 minggu sebelum dana tersebut akan terpakai, sehingga pemerintah desa dengan pihak stakeholders sama-sama tidak merasa dirugikan.

\section{UCAPAN TERIMA KASIH}

Puji syukur penulis panjatkan kehadirat Allah Subhanahu Wata'ala karena dengan rahmat dan hiyah-Nyalah sehingga penulis dapat menyelesaikan artikel ini dengan judul "Efektivitas Pengelolaan Alokasi Dana Desa pada Desa Silondou Kecamatan Basi Dondo Kabupaten Tolitoli" sesuai batas waktu yang telah ditentukan.

Artikel ini dapat terselesaikan berkat adanya dukungan dan kontribusi moril yang sangat berharga terutama dari pihak keluarga hingga saat ini. Serta bantuan yang diberikan oleh pihak Kantor Desa Silondou Kecamatan Basi Dondo Kabupaten Tolitoli yang telah memberikan data-data yang dibutuhkan penulis sehingga artikel ini dapat diselesaikan.

\section{DAFTAR PUSTAKA}

Arikunto, Suharsimi. 2006. Prosedur Penelitian: Suatu Pendekatan Praktik. Edisi Revisi VI. Jakarta : PT Rineka Cipta.
Bachtiar, I. H., \& Ela Elliyana. (2020). Determinan upaya pencegahan fraud pemerintah desa. Imanensi: Jurnal Ekonomi, Manajemen, Dan Akuntansi Islam, 5(2), https://doi.org/10.34202/imanensi.5.2.202 0.61-68

Bachtiar, I. H., \& Elliyana, E. Fraud Prevention in Bulukumba Regency, Indonesia.

Dunn, William N. 2000. Pengantar Analisis Kebijakan Publik. Yogyakarta : Gadjah Mada University Press.

Effendi, Guntur. 2009. Pemerdayaan Ekonomi Rakyat. Jakarta : Cv Sagung Seto.

Halim, Abdul.2002. Akuntansi Keuangan Daerah. Jakarta : Salemba Empat.

Haris, Syamsudin. 2005.Desentralisasi dan Otonomi Derah. Jakarta: LIPI Pers. Kansil, Christine. 2001. Kitab UndangUndang Otonomi Daerah. Jakarta : PT. Pradnya Paramita.

Kuncoro, Mudrajad.2004. Otonomi Dan Pembangunan Daerah. Yogjakarta : Erlangga.

Kurniawan, Agung. 2005. Transformasi Pelayanan Publik. Yogyakarta: Pembaruan.

.Laporan Anggaran Pendapatan dan Bealanja Desa(2014-2019). Tolitoli : Kantor Desa Silondou.

Mardiasmo.2002. Akuntasi Sektor Publik. Yogjakarta : Andi Offset. Nurcholis, Hanif. Teori dan Praktek Pemerintahan dan Otonomi Daerah. 
Jakarta : PT. Gramedia Widiasarana Indonesia.

\section{Pengelolaan Alokasi Dana Desa} Dalam Pemberdayaan Masyarakat Desa (Studi Pada Desa Wonorejo Kecamatan Singosari Kabupaten Malang). Skripsi (tidak diterbitkan) Jurusan Administrasi Publik, Universtas Brawijaya, Malang.

Sadono, Sukirno. 2004. Ekonomi Mikro. Jakarta : PT Raja Grafindo Persada Sudijono, Anas. 2009. Pengantar Statistik Pendidikan. Jakarta : Rajawali

Syahhelmi. 2008. Analisis elastisitas, efisiensi, dan efektivitas. Medan : Universitas Suamatra Utara Medan. Tampubolo.

Richardo Juniaster. 2013. Pelaksanaan Prinsip Good Governance dalam Alokasi Dana Desa (ADD) Di Desa Teluk Bakau Kecamatan Gunung Kijang Kabupaten Bintan Tahun 2013. Skripsi (tidak diterbitkan) Universitas Maritim Raja Haji, Bintan.

Wasistiono, Sadu.2000. Pengantar Ekologi Pemerintahan. Jatinegoro : IPDN Press Winarno, Budi. 2007. Kebijakan Publik, Teori Dan Proses. Yogyakarta : Media Pressindo.

Widjaya, H.A.W. 2004. Otonomi Daerah dan Daerah Otonom. Jakarta : PT. Grafindo Persada.

Depdagri. Kepmendagri. No.6090.900327. Kriteria Rasio Efektivitas. Online (diakses 24 April 2015).

Peraturan Pemerintah nomor 72 tahun 2005 Tentang Alokasi Dana Desa. Online (diakses pada 2 mei 2015).
Permendagri No 66 tahun 2007 tentang Pemerdayaan Masyarakat Desa.

Online (diakses pada 2 mei 2015)

Surat Edaran Menteri Dalam Negeri Nomor 140/640/SJ Tahun 2005 tentang Pedoman Alokasi Dana Desa (ADD) dari Pemerintah Kabupaten/Kota kepada Pemerintah Desa. Online (diakses pada 2 mei 2015). 